\title{
Development and Validation of the Questionnaire for the Evaluation of Knowledge about Herbal Preparations (QEK-HP)
}

\author{
Snježana Mirković ${ }^{1}$, Slobodan Janković², Jelena Džudovićs ${ }^{3}$ Vladimir Gužvić4 \\ ${ }^{1}$ University of Bijeljina, Faculty of Pharmacy, Bijeljina, Bosnia and Herzegovina \\ ${ }^{2}$ University of Kragujevac, Faculty of Medical Sciences, Kragujevac, Serbia \\ ${ }^{3}$ Military Medical Center Belgrade, Belgrade, Serbia \\ ${ }^{4}$ Health Insurance Fund of Republic of Srpska, Banja Luka, Bosnia and Herzegovina
}

\section{SUMMARY}

Phytopreparations, in addition to the pharmacological activity and positive effects on health, can lead to side effects, toxic effects, allergic reactions, as well as the interaction of conventional and herbal medicines. Despite this, there is a generally positive attitude that herbal medicines and herbal dietary supplements are safe and harmless to health and are most often used on its own initiative, without consultations with a pharmacist or a doctor. The aim of this study was to develop and validate a questionnaire for measuring the general knowledge about phytopreparations.

The study was designed as an observational, prospective cross-sectional study, intended for the valiation of the original epidemiological questionnaire to evaluate the knowledge about phytopreparations. The sample consisted of 218 respondents, who were visiting private pharmacies at the territory of Bijeljina, in February and March 2016.

The final version of the questionnaire for the evaluation of knowledge about herbal preparations had good internal consistency $(\alpha=0.849)$ and homogeneity when randomly splitting the questionnaire into two parts $(\alpha=0.731 ; 0.788)$. Exploratory factor analysis singled out two factors.

Based on the results of the study, it can be concluded that the questionnaire was a valid and reliable instrument for the evaluation of general knowledge about safety of use of phytopreparations. This is very important because the evaluation of knowledge could lead to undertaking measures for improving it, which would reduce the potential adverse reactions and interactions of herbal preparations with conventional drugs, and the application would become safe and optimal.

Key words: questionnaire, herbal preparations, knowledge, validation

Corresponding author:

Snježana Mirković

Email: snjezanam1983@gmail.com 


\section{INTRODUCTION}

Phytotherapy, as part of the complementary pharmacotherapy is a therapeutic concept of treatment based on the use of natural raw materials (drugs) and herbal preparations (phytopreparations), which are used prophylactically in treating mild forms of the disease, or as adjuvant therapy in the treatment of chronic diseases (1). The increasing orientation towards phytotherapy is the result of the tendency towards improving health, but also the dissatisfaction of patients with conventional drugs in terms of safety, efficiency and cost, and the attitude that the use of herbal preparations is safe and secure $(1,2)$. So today, at the beginning of the $21^{\text {st }}$ century, interest in phytopreparations is increasing, and according to the World Health Organization (WHO), most of the world's population in health care relies mainly on traditional methods of treatment by using herbs (3). Although, very often the words "natural" or "herbal origin" are identified with the meaning of "safe", herbs are a natural laboratory where complex mixtures of organic compounds are synthesized, often of variable content. In addition to the pharmacological activities and positive effects on health, they may lead to adverse effects, toxic effects, allergic reactions, as well as the interaction of conventional and herbal medicines (4).

Nevertheless, there is generally a positive attitude towards the use of phytopreparations. It is thought that herbal preparations and herbal dietary supplements are safe and harmless to human health and are commonly used on person's own initiative, without consultations with a pharmacist or a doctor (5-8).

Although there are a number of studies, where besides the evaluation of the attitude on phytopreparations, estimation of knowledge about the use, safety of use of herbal preparations is performed, these studies are mainly related to attitudes and knowledge of students of pharmacy, medicine, pharmacists, doctors and other healthcare workers (9-14). The questionnaires used in those studies were not used on respondents that are engaged in non-medical professions and thus are not suitable for testing the general knowledge about phytopreparations.

There have been several studies that evaluate the knowledge of certain population groups on phytopreparations (15-17). Americans, sixty years old and older, were subjected to testing related to the use of phytopreparations, the attitudes towards phytopreparations, but also the knowledge about the safety of the use and regulation of herbal praparations with regard to safety testing, quality and labeling of the product (15). In a study conducted in urban areas of the Amazon, women's knowledge of the names of herbs that are used for specific indications such as flu, cold, diarrhea, contraception, gynecological problems and wound healing (16) was evaluated. The evaluation of knowledge about herbal preparations was carried out and in Malaysia, where the respondents were women in the prenatal and postnatal period. The study questioned the knowledge of the purity, the possibility of contamination of herbal preparations, then the knowledge about the process of preparing herbal preparations and knowledge of the potential impact of phytopreparations on the fetus, abortion, intrauterine death, a positive health impact on mother and child, and the like (17). The questionnaires used in these studies were not validated.

The aim of this study was the development and validation of a questionnaire, as an instrument for the evaluation of general knowledge about phytopreparations.

\section{MATERIALS AND METHODS}

\section{The development of the questionnaire}

The content of the questionnaire was designed based on a systematic review of the existing, relevant literature related to the knowledge of herbal phytopre parations. While developing the questionnaire, the content of the scale was validated by experts in the field of pharmacognosy (Ph.D Vanja Tadić and Ph.D Ivana Arsić) and two focus groups. The questionnaire initially consisted of 22 questions. Respondents were asked to respond to a five-point Likert scale, choosing an answer related to the extent of agreeing with the statement (1-completely disagree, 2-statements were formulated as affirmative and negative in order to minimize the tendency of respondents to respond in consistent way, using answers of only one part of the Likert scale. For this purpose, the questionnaire included a question that stands out from the rest and reflects the social desirability.

Primarily, the questionnaire was adapted according to the study of prevalidation, which was conducted on a small number of respondents. After submission of the questionnaire, a brief interview was carried out with the aim to validate the comprehensibility, clarity, precision, and the need to correct the questionnaire. 


\section{Population and sampling}

The study was designed as an observational, prospective, cross-sectional study, intended for validation of the original epidemiological questionnaire for the evaluation of knowledge about phytopreparations. The sample included 218 participants, aged 1880, of different gender diversity, socio-demographic characteristics and health condition, who were using the services of the private pharmacies at the territory of Bijeljina, in February and March 2016.

Participants were chosen as a suitable sample and were previously informed in writing about the research. Just before completing the questionnaire, socio-demographic characteristics of participants were collected, such as: gender (male, female), age (18-29, 30$49,50-65,>65$ years old), level of education expressed in the number of years spent on education $(\leq 4,8$, $11,12,15,16-18,>18$ years) and the health status of patients with respect to the presence of chronic disease (chronic disease: yes/no). All participants were asked to anonymously and voluntarily answer the questions in the structured questionnaire.

The study was approved by the Ethics Committee of the Clinical Center in Kragujevac, and all participants gave written consent before completing the questionnaire. The patients were treated with due respect and care, according to the principles stated in the Declaration of Helsinki.

\section{Reduction of the number of questions}

In order to detect and eliminate the questions that are less valuable, the correlation matrix was design ed. Questions with low correlation (less than 0.2) were suggested for elimination. The value of the correlation of each question with an overall score of all other questions ("corrected" overall score) was analyzed by Spearman's correlation coefficient. Questions with low correlation (less than 0.3) were eliminated. Variance and mean value were used as one of the criteria for the reduction of the number of questions (18). The application of factor analysis reduces the number of questions, or eliminates questions that do not fit into the model (19).

\section{Reliability testing}

Internal reliability or internal consistency of the questionnaire is a measure of the homogeneity of the questions in the questionnaire, i.e. it represents the extent to which questions measure the same attribute. To express the internal reliability Cronbach's alpha coefficient was calculated for the entire questionnaire. The questionnaire has good internal consistency if the Cronbach's alpha coefficient is equal or larger than 0.7 , if it is larger than 0.8 , it indicates good consistency, and if it is larger than 0.9 , the consistency of the questionnaire is excellent (20). Another aspect of the reliability of the questionnaire is based on the correlation between the parts of the questionnaire. Using the split-half method, the questionnaire was divided randomly into two parts, and the Cronbach's alpha coefficient was calculated separately for both parts of the questionnaire, which ensured the external consistency of the instrument. Based on the reliability (alpha for both parts), the number of questions and the average correlation of the questions of both halves of the questionnaire, the reliability of the whole questionnaire were assessed by calculating the Cronbach's alpha using the Spearman-Brown's "predictive" formula (21). This is another way of evaluating the reliability of the whole questionnaire. Thirdly, for each question mean scores and their variances were calculated, in order to check their suitability for measurement of whole extent of knowledge.

\section{Exploratory factor analysis}

After the reduction of the number of questions, exploratory factor analysis was used for the detection of categories of similar statements in the questionnaire (22), and defining the number of factors that the questionnaire measured. To confirm the possibility of performing a factor analysis, it was necessary to meet the requirements by using Kaiser-Meyer-Olkin's measure of sam-pling adequacy and Bartlett's Test of Sphericity.

By applying "The Eigenvalues-greater-than-one" rule, and based on the graphic Scree plot, factors were extracted. After extraction of factors, the orthogonal rotation referent axis was made using the Varimax method, and then re-extraction of factors, using the same criteria. In factors, questions were grouped according to the respective common characteristic according to which they explain the same phenomenon, and then they were named.

\section{Validity}

To ensure the content validity, an independent expert was consulted, who was to estimate that the questions were characteristic for the measured occur- 
ence (18). Content validity was analyzed by a critical examination of the questionnaire by experts in the field of pharmacognosy (PhD. Vanja Tadić and Ph.D Ivana Arsić) and two focus groups, which consisted of five doctors and five masters of pharmacy.

Criterion validity was estimated based on correlation with a similar questionnaire, which is considered the "gold" standard (i.e. "criterion") and which measures the occurrence of interest (23). Convergent and divergent validity was explored by examining its relationship with other scales, mostly similar or completely different. However, due to the unavailability of quest- ionnaires to measure a similar concept, construct validity was established via the 'known-groups method', comparing two groups that were expected to differ in their knowledge of phytopreparations (24). As standard, control group of this study included 20 pharmacists, whose knowledge was evaluated and compared with the knowledge of respondents. In addition, within the construct validity, the evaluation of the correlation of knowledge of highly educated respondents (university education, completed post-graduate studies) and the rest of the participants was conducted.

Table 1. Socio-demographic characteristics of respondents

\begin{tabular}{|c|c|c|c|c|c|c|c|}
\hline \multirow[t]{3}{*}{ Gender } & \multicolumn{4}{|c|}{ Male } & \multicolumn{3}{|c|}{ Female } \\
\hline & \multicolumn{4}{|c|}{65} & \multicolumn{3}{|c|}{153} \\
\hline & \multicolumn{3}{|c|}{$29.8 \%$} & & \multicolumn{3}{|c|}{$70.2 \%$} \\
\hline \multirow[t]{3}{*}{ Age (years) } & \multicolumn{2}{|c|}{ 18-29 } & \multicolumn{2}{|l|}{$30-40$} & $50-65$ & \multicolumn{2}{|c|}{$>65$} \\
\hline & \multicolumn{2}{|c|}{43} & \multicolumn{2}{|l|}{87} & 67 & \multicolumn{2}{|c|}{21} \\
\hline & \multicolumn{2}{|c|}{$19.7 \%$} & $39.9 \%$ & & $30.7 \%$ & \multicolumn{2}{|c|}{$9.6 \%$} \\
\hline \multirow[t]{3}{*}{ Education (years) } & 4 & 8 & 11 & 12 & 15 & $16-18$ & $>18$ \\
\hline & 3 & 12 & 36 & 82 & 34 & 46 & 5 \\
\hline & $1.4 \%$ & $5.5 \%$ & $16.5 \%$ & $37.6 \%$ & $15.6 \%$ & $21.1 \%$ & $2.3 \%$ \\
\hline \multirow[t]{3}{*}{ Chronic disease } & \multicolumn{4}{|c|}{ Yes } & \multicolumn{3}{|c|}{ No } \\
\hline & \multicolumn{4}{|c|}{86} & \multicolumn{3}{|c|}{132} \\
\hline & \multicolumn{3}{|c|}{$39.4 \%$} & & \multicolumn{3}{|c|}{$60.6 \%$} \\
\hline
\end{tabular}

Within the construct validity, a divergent validity is determined, whereby the respondents filled out the questionnaire that measures completely different phenomenon - A Short Subjective Well-being Scale (SSWS) $(25,26)$. The use of SSWS was approved by the author V. Jovanović, a psychologist at the University of Novi Sad.

All calculations were performed by SPSS statistical software, version 18.0.

\section{RESULTS}

In the validation study of the questionnaire, 223 respondents participated. Table 1 shows the sociodemographic characteristics of respondents. The mean value of the results referring to the knowledge was 37.79 $(\mathrm{Sd}=8.467)$. Questionnaires that were partially completed and in which the answer to the question of social desirability suggested that the answers were randomly chosen, were not included in further analysis and data processing. The final size of the sample consisted of 218 participants.

\section{Reduction of the number of questions}

In order to detect and eliminate the less valuable questions in the original questionnaire of 22 questions, the following parameters were deter-mined: interitem correlation of the questions, "corrected" overall score, standard deviation, mean scores for each question, skewness and kurtosis. Stated values of the final version of the questionnaire (QEK-HP) are shown in Table 2.

Once the less valuable questions were identified, the elimination of the number of questions was made, and they were reduced to 10 questions. The final version of the questionnaire, after the elimination of questions, on which the factor analysis would be carried out, is presented in Appendix.

\section{Reliability analysis}

The value of Cronbach's alpha of the final questionnaire was 0.849 . When the questionnaire was divided into two parts using a split-half method, the value of Cronbach's alphas were 0.731 and 0.788 , 
Table 2. Mean values, standard deviation, "corrected" overall score, skewness and kurtosis of responses to items of the QEK-HP (the responses are rated from 1 to 5 on a Likert scale).

\begin{tabular}{cccccc}
\hline \hline Question & Mean values & $\begin{array}{c}\text { Standard } \\
\text { deviation }\end{array}$ & $\begin{array}{c}\text { "Corrected" } \\
\text { overall score }\end{array}$ & Skewness & Kurtosis \\
\hline 1. & 3.220 & 1.387 & 0.563 & -0.389 & -1.253 \\
2. & 3.810 & 1.269 & 0.442 & -0.898 & -0.303 \\
3. & 3.520 & 1.354 & 0.596 & -0.475 & -1.142 \\
4. & 3.860 & 1.375 & 0.463 & -0.878 & -0.634 \\
5. & 3.780 & 1.260 & 0.541 & -0.878 & -0.208 \\
6. & 3.830 & 1,257 & 0,436 & -0.870 & -0.350 \\
7. & 3.930 & 1.299 & 0.562 & -0.954 & -0.435 \\
8. & 4.000 & 1.212 & 0.556 & -1.011 & -0.170 \\
9. & 4.000 & 1.263 & 0.550 & -1.109 & -0.018 \\
10. & 3.820 & 1.316 & 0.555 & -0.852 & -0.544 \\
\hline
\end{tabular}

Table 3. The distribution of questions into factors after Varimax rotation and the names of the factors.

\begin{tabular}{|c|c|c|}
\hline Questions & $\begin{array}{l}\text { Factor 1: } \\
\text { General questions } \\
\text { about the safe use of } \\
\text { phytopreparations }\end{array}$ & $\begin{array}{c}\text { Factor 2: } \\
\text { The safe use of } \\
\text { phytopreparations in } \\
\text { vulnerable groups }\end{array}$ \\
\hline $\begin{array}{c}\text { Herbal preparations are "natural" and can not } \\
\text { cause adverse effects. }\end{array}$ & 0.473 & $0.564^{*}$ \\
\hline Herbal preparations can not cause allergies. & 0.231 & $0.582^{*}$ \\
\hline $\begin{array}{l}\text { It is not necessary to control the safety and efficacy } \\
\text { of herbal preparations. }\end{array}$ & 0.425 & $0.658^{*}$ \\
\hline $\begin{array}{l}\text { Herbal preparations may be contaminated and can } \\
\text { contain heavy metals or bacteria. }\end{array}$ & 0.048 & $0.742^{*}$ \\
\hline Herbal preparations can be toxic. & 0.099 & $0.788^{*}$ \\
\hline $\begin{array}{l}\text { The use of herbal preparations in children is } \\
\text { completely safe. }\end{array}$ & $0.749^{*}$ & 0.302 \\
\hline $\begin{array}{l}\text { During pregnancy and breastfeeding herbal } \\
\text { preparations should be used cautiously with the } \\
\text { help of expert consultations. }\end{array}$ & $0.780^{*}$ & 0.256 \\
\hline $\begin{array}{l}\text { Elderly people should be precautious when using } \\
\text { herbal preparations. }\end{array}$ & $0.798^{*}$ & 0.171 \\
\hline $\begin{array}{c}\text { Patients with chronic diseases (diabetes, liver, } \\
\text { kidney and heart disease, etc.) can safely use } \\
\text { herbal preparations. }\end{array}$ & $0.734^{*}$ & 0.101 \\
\hline $\begin{array}{l}\text { Herbal preparations can affect the effect of } \\
\text { medications. }\end{array}$ & 0.220 & $0.480^{*}$ \\
\hline
\end{tabular}

* The highest factor loadings for each item of the QEK-H 
which was then used to calculate the SpearmanBrown coefficient of the entire questionnaire using the Spearman-Brown "prediction" formula. The value of the reliability of the questionnaire as a whole, calculated in this way, was 0.798 .

\section{Factor analysis}

The value of Kaiser-Meyer-Olkin test was 0.764, and it exceeded the recommended 0.6, while Bartlett's test of sphericity showed statistical signifycance $\left(x^{2}=858.910, \mathrm{df}=45\right.$, sig. $\left.=0.000\right)$, which confirms the possibility of performing a factor analysis. After orthogonal rotation of reference axis using the Varimax method, two factors that explain $55.505 \%$ of the total variance singled out. The first factor bears 4.312 eigenvalues (43.136\% of variance), and the second factor carries 1.237 eigenvalues ( $12.369 \%$ of variance). The distribution of questions into factors after Varimax rotation and the names of the factors are shown in Table 3.

\section{Validity}

Content validity was analyzed by two focus groups. Based on the opinions, the questions were clear, understandable, accurate, relevant and on a scale from 1 to 5 ranked with 4 or 5 points. On the basis of content validation there was no replacement or omission of questions, while only three questions were slightly modified. Based on the correlation coefficient of the QEK-HP and SSWS $(\mathrm{Q}=-0.069)$, it can be concluded that there is no high correlation, which supports the divergent validity. The simple independent $t$-test showed a significant difference $(p=0.000)$ in the level of knowledge about phytopreparations, between the two groups (20 pharmacists and respondents). By using the one-way ANOVA, a statistically significant difference $(p=0.033)$ was present in the level of knowledge between highly educated respondents and the rest of the participants.

\section{DISCUSSION}

The results of the conducted study suggested that the final version of the questionnaire for the evaluation of knowledge about herbal preparations (QEK-HP) has good internal consistency (0.849) and homogeneity when randomly splitting a questionnaire into two parts. Exploratory factor analysis singled out two factors: "General questions about the safe use of phytopreparations" and "The safe use of phytoprepa rations in vulnerable groups".

Questions related to the side effects of commonly used herbal preparations and potential interactions with medications (St. John's wort, garlic, bearberry tea, green tea, marshmallow, hawthorn, ginkgo, senna, buckthorn, garlic) were eliminated from the primary version of the questionnaire, which indicates the lack of knowledge and the need for more education and information.

The first factor consists of six questions and shows considerable internal consistency (0.778). The issues covered by these factors relate to safety of using phytopreparations, potential side effects and interactions with medications, need to control the quality i.e. safety and efficacy of phytopreparations, the possibility of causing allergies after application, potential toxicity and safety with regard to bacterial contamination and the presence of heavy metals. In the last two decades the application and popularity of phytopreparations is in the expansion. Based on the large number of studies, there is an opinion that the herbal preparations are safe and harmless to human health, regardless of many reported adverse reactions of herbal active ingredients, contaminants, as well as interaction with synthetic drugs (4).

Based on the research conducted in Serbia and Saudi Arabia, there is the opinion that the herbal preparations and herbal dietary supplements are safe and harmless to health. Only one half of the participants believe that the combined application of phytopreparations and conventional medications is not safe $(5,6)$.

In Kansas City, a survey was conducted among the geriatric population, where $66 \%$ of respondents believed that herbal medicines are safe for use, while a smaller number (27\%) knew that the purity of herbal preparations is questionable (5). The second factor has singled out four questions and shows a good internal consistency $(0.815)$. The questions are related to the safety of use of herbal preparations in pregnant women, nursing mothers, children, geriatric population and patients with chronic disease. In Italy, the survey was conducted among elderly patients who were treated with warfarin. Most respondents believed that the use of phytopreparations is useful and that there is no risk of adverse reactions and interactions. Out of 294 patients, 69 used herbal preparations during the treatment with warfarin, 6 of them reported adverse reactions, and 16 of them an unstable value of INR (8). Based on these data, patients' knowledge about 
the possible interactions of herbal preparations with warfarin can be assessed in an indirect way.

Non-validated questionnaires were used as instruments in these studies, and their reliability and other psychometric properties have not been presented. In addition to the evaluation of knowledge, they estimate the use and the attitude on herbal preparations. Thus, the results of previously mentioned studies cannot be compared with the results of questionnaire used in our study.

Content validity was confirmed by a critical examination of the questionnaire by experts in the field of pharmacognosy and two focus groups. Within the construct validity, divergent validity was confirmed, with the help of SSWS (Short Subjective Well-being Scale). The limiting factor of this study is the lack of the "gold standard" to confirm the criterion validity. Although there is a number of studies carried out with the aim of evaluating the knowledge of herbal preparations among students of pharmacy, medicine, pharmacists, doctors and other healthcare professionals $(10,12,13)$, these questionnaires have not been validated and adequate for testing the general knowledge about herbal preparations. In addition, there are validated questionnaires that measure the attitude of healthcare professionals about complementary alternative medicine (CAM) (27-29). They evaluated a differrent concept; a CAM represents the broader concept compared to phytopreparations. Since there is no questionnaire in Serbian language, which would measure a similar concept, the control study was used as a standard, and it compared the results of the knowledge of the control group (pharmacists) and the test group. The research results showed that there was an expected, significant difference in the level of knowledge about the phytopreparations between the two groups, which confirms the known-groups validity. The significant differrence between total knowledge score of highly educated respondents in relation to the rest of the participants indicates that the questionnaire has a good construct validity.

The main limitation of this study is that it was not possible to determine the temporal stability by retesting the respondents after 15 to 20 days, because it was not possible to organize another meeting with participants who were surveyed at various locations. Also, criterion validity has not been established because adequate questionnaire that measures similar phenomenon was not available. One of the limitations is the fact that the participants themselves filled out the questionnaire.

\section{CONCLUSION}

The questionnaire for the evaluation of knowledge about herbal preparations (QEK-HP) is reliable and valid instrument for measuring the general knowledge about the safety and reliability of the herbal preparations use. This is very important because the evaluation of knowledge could lead to undertaking some measures for improving it. It would further on reduce the potential adverse reactions and interactions of phytopreparations with conventional drugs, and the application would become safe and the optimal. The additional knowledge could be enriched through school education, various workshops in local communities, but mostly by receiving useful information by health professionals.

\section{Acknowledgement}

The authors are grateful to Assistant professor Jovanovic Veljko, University of Novi Sad, for giving permission to use the Short Subjective Well-being Scale in Serbian language. 


\section{Appendix}

The questionnaire for the evaluation of knowledge about of herbal preparations (QEK-HP)

The answers to each of the 10 questions were rated as the following: 1-"completely disagree", 2"partially disagree", 3-"neither agree nor disagree", 4-"partially agree", and 5-"completely agree".

Please indicate your level of agreement with each of the following items (circle the number 1-5).

1. Herbal preparations are "natural" and cannot cause adverse effects.

1. completely disagree

2. partially disagree

3. neither agree nor disagree

4. partially agree

5. completely agree

2. Herbal preparations cannot cause allergies.

6. completely disagree

7. partially disagree

8. neither agree nor disagree

9. partially agree

10. completely agree

3. It is not necessary to control the safety and efficacy of herbal preparations.

11. completely disagree

12. partially disagree

13. neither agree nor disagree

14. partially agree

15. completely agree

4. Herbal preparations may be contaminated, and can contain heavy metals or bacteria.

1. completely disagree

2. partially disagree

3. neither agree nor disagree

4. partially agree

5. completely agree

5. Herbal preparations can be toxic.

1. completely disagree 
2. partially disagree

3. neither agree nor disagree

4. partially agree

5. completely agree

6. Herbal preparations can affect the effect of medications.

1. completely disagree

2. partially disagree

3. neither agree nor disagree

4. partially agree

5. completely agree

7. The use of herbal preparations in children is completely safe.

1. completely disagree

2. partially disagree

3. neither agree nor disagree

4. partially agree

5. completely agree

8. During pregnancy and breastfeeding herbal preparations should be used cautiously with the help of expert consultations.

1. completely disagree

2. partially disagree

3. neither agree nor disagree

4. partially agree

5. completely agree

9. Elderly people should be precautious when using herbal preparations

1. completely disagree

2. partially disagree

3. neither agree nor disagree

4. partially agree

5. completely agree 
10. Patients with chronic diseases (diabetes, liver, kidney and heart disease, etc.) can safely use herbal preparations.

1. completely disagree

2. partially disagree

3. neither agree nor disagree

4. partially agree

5. completely agree

\section{References}

1. Dordević S, Dickov A, Pavkov S et al. Manufacturing process of high quality phytopreparation on example of herbal sedative. Med Pregl 2013; 66 : 170-6.

https://doi.org/10.2298/MPNS1304170D

2. Fakeye TO, Adisa R, Musa IE. Attitude and use of herbal medicines among pregnant women in Nigeria. BMC Complement Altern Med 2009; 9: 53. https://doi.org/10.1186/1472-6882-9-53

3. WHO Traditional Medicine Strategy 2002-2005. World Health Organization, Geneva, 2002

4. Bent S, Ko R. Commonly used herbal medicines in the United States: a review. Am J Med 2004; 116: 478-85.

https://doi.org/10.1016/j.amjmed.2003.10.036.

5. Samojlik I, Mijatović V, Gavarić N, Krstin S, Božin B. Consumers' attitude towards the use and safety of herbal medicines and herbal dietary supplements in Serbia. Int J Clin Pharm 2013; 35: 835-40. https://doi.org/10.1007/s11096-013-9819-3

6. Amal K S. Attitudes and Beliefs of Consumers of Herbal Medicines in Riyadh, Saudi Arabia. J Community Med Health Educ 2014; 4 :269
7. Awad A, Al-Shaye D. Public awareness, patterns of use and attitudes toward natural health products in Kuwait: a cross-sectional survey. BMC Complement Altern Med $2014 ; 14:$ : 205. https://doi.org/10.1186/1472-6882-14-105

8. Cuzzolin L, Benoni G. Attitudes and knowledge toward natural products safety in the pharmacy setting: an Italian study. Phytother Res 2009; 23 : 1018-23.

https://doi.org/10.1002/ptr.2745

9. Bacchini M, Cuzzolin L, Camerlengo T et al. Phytotherapic compounds: the consumer-pharmacist relationship. Drug Saf 2008; 31: 424-27. https://doi.org/10.2165/00002018-200831050-00008

10. Chang ZG, Kennedy DT, Holdford DA, Small RE. Pharmacists' knowledge and attitudes toward herbal medicine. Ann Pharmacother 2000; 34 (6): 750755.

https://doi.org/10.1345/aph.19263

11. Abahussain NA, Abahussain EA, Al-Oumi FM. Pharmacists' attitudes and awareness towards the use and safety of herbs in Kuwait. Pharm Pract (Granada). 2007; 5: 125 -9.

https://doi.org/10.4321/S1886-36552007000300005 
12. Duraz AY, Khan SA. Knowledge, attitudes and awareness of community pharmacists towards the use of herbal medicines in muscat region. Oman Med J 2011; 26: 451-3. https://doi.org/10.5001/omj.2011.115

13. Clement $\mathrm{YN}$, Williams AF, Khan $\mathrm{K}$ Et al. A gap between acceptance and knowledge of herbal remedies by physicians: the need for educational intervention. BMC Complement Altern Med 2005; 5:20.

\section{https://doi.org/10.1186/1472-6882-5-20}

14. Zimmerman C, Kandiah J. A pilot study to assess students' perceptions, familiarity, and knowledge in the use of complementary and alternative herbal supplements in health promotion. Altern Ther Health Med 2012; 18: 28-33.

15. Marinac JS, Buchinger CL, Godfrey LA et al. Herbal products and dietary supplements: a survey of use, attitudes, and knowledge among older adults. J Am Osteopath Assoc 2007; 107: 1320.

16. Wayland C, Slattery Walker L. Length of residence, age and patterns of medicinal plant knowledge and use among women in the urban Amazon. J Ethnobiol Ethnomed 2014; 10:25.

\section{https://doi.org/10.1186/1746-4269-10-25}

17. Kim Sooi L, Lean Keng S. Herbal Medicines: Malaysian Women's Knowledge and Practice. Evid Based Complement Alternat Med 2013; 2013: 438139

18. Janković S. Design of research. Medicinsko društvo za racionalnu terapiju Republike Srbije, Kragujevac, 2016: 100-1. (in Serbian)

19. Norman GR, Streiner DL. PDQ Statistics. 3th ed. BC Decker Inc, Ontario, 2003.

20. Fayers PM, Machin D. Quality of life: Assessment, Analysis and Interpretation of patient reported outcomes. 2nd ed. John Wiley \& Sons, Chichester, 2007.

https://doi.org/10.1002/9780470024522
21. Streiner DL, Norman GR. Health Measurement Scale-apractical guide to their development and use. 4th edition. Oxford University Press, Oxford, 2008.

https://doi.org/10.1093/acprof:oso/9780199231881. $\underline{001.0001}$

22. DeVellis RF. Scale Development: Theory and Applications (Applied Social Research Methods), 3th edition, SAGE Publications, Inc., Los Angeles, 2012.

23. Chen AY, Frankowski R, Bishop-Leone J et al.. The development and validation of a dysphagiaspecific quality-of-lifequestionnaire for patients with head and neck cancer: the M. D. Anderson dysphagia inventory. Arch Otolaryngol Head Neck Surg 2001; 127: 870-6.

24. Bolarinwa OA. Principles and methods of validity and reliability testing of questionnaires used in social and health science researches. Niger Postgrad Med J 2015; 22: 195-201.

https://doi.org/10.4103/1117-1936.173959

25. Jovanovic V, Novovic Z. Short Subjective Wellbeing Scale - new instrument for estimate of positive mental health. Primenjena psihologija 2008; 1: 77-94. (in Serbian)

26. Jovanovic V. Validation of the Short Subjective Well-being Scale. Primenjena psihologija 2010; 3: 175-190. (in Serbian)

27. Lie D, Boker J. Development and validation of the CAM Health Belief Questionnaire (CHBQ) and CAM use and attitudes amongst medical students. BMC Med Educ 2004; 4:2. https://doi.org/10.1186/1472-6920-4-2

28. Schneider CD, Meek PM, Bell IR. Development and validation of IMAQ: Integrative Medicine Attitude Questionnaire. BMC Med Educ 2003; 3:5. https://doi.org/10.1186/1472-6920-3-5

29. Kim JH, Lee JB, Lee DC. Validation of the Korean Integrative Medicine Attitude Questionnaire (IMAQ). Korean J Fam Med 2011; 32: 197-204. https://doi.org/10.4082/kjfm.2011.32.3.197 


\title{
Sastavljanje i vrednovanje upitnika za procenu znanja o biljnim preparatima (QEK-HP)
}

\author{
Snježana Mirković ${ }^{1}$, Slobodan Janković ${ }^{2}$, Jelena Džudović ${ }^{3}$, Vladimir Gužvić ${ }^{4}$ \\ ${ }^{1}$ Univerzitet u Bijeljini, Farmaceutski fakultet, Bijeljina, Bosna i Hercegovina \\ ${ }^{2}$ Univerzitet u Kragujevcu, Fakultet medicinskih nauka, Kragujevac, Srbija \\ ${ }^{3}$ Vojno-medicinski centar Beograd, Beograd, Srbija \\ ${ }^{4}$ Fond zdravstvenog osiguranja Republike Srpske, Bosna i Hercegovina
}

\section{SAŽETAK}

Fitopreparati, pored farmakološke aktivnosti i pozitivnih efekata na zdravlje, mogu dovesti do neželjnog delovanja, toksičnih efekata, alergijskih reakcija, kao i interakcija konvencionalnih i biljnih lekova. Uprkos tome, generalno vlada pozitivan stav da su biljni lekovi i biljni dijetetski suplementi bezbedni i bezopasni po zdravlje i najčešće se koriste na sopstvenu inicijativu, bez konsultacije sa farmaceutom ili ljekarom. Cilj ove studije bila je izrada i validacija upitnika za evaluaciju opšteg znanja o fitopreparatima.

Studija je dizajnirana kao opservaciona, prospektivna studija preseka, namenjena validaciji origina-lnog epidemiološkog upitnika za evaluaciju znanja o fitopreparatima. Uzorak je činilo 218 ispitanika, koji su posećivali privatne apoteke na teritoriji Bijeljine, tokom februara i marta 2016. godine.

Krajnja verzija Upitnika za procenu znanja o biljnim preparatima, poseduje dobru unutrašnju konzistentnost $(\alpha=0,849)$ i homogenost prilikom nasumičnog deljenja upitnika na dva dela $(\alpha=0,731 ; 0,788)$. Eksplorativnom faktorskom analizom ektrahovana su dva faktora.

Na osnovu rezultata studije može se zaključiti da je upitnik validan i pouzdan instrument za procenu opšteg znanja o bezbednosti primene fitopreparata. Ovo je veoma bitno jer bi se evaluacijom znanja, mogle preduzeti mere za unapređenje istog, čime bi se smanjile potencijalne neželjene reakcije i interakcije fitopreparata sa konvencionalnim lekovima, a primena postala bezbedna i optimalna.

Ključne reči: upitnik, biljni preparati, znanje, validacija 